\title{
Arkadiusz Tuziak
}

Uniwersytet Rzeszowski

\section{Innowacyjność w organizacjach sektora samorządowego}

STRESZCZENIE $W$ artykule podjęto zagadnienie innowacyjności $W$ organizacjach sektora samorządowego. W części wstępnej scharakteryzowano ogólne społeczne prawidłowości dotyczące innowacyjności w organizacjach, ze szczególnym uwzględnieniem organizacji typu biurokratycznego. W części zasadniczej skupiono się na ukazaniu zarówno indywidualnych, jak i instytucjonalnych uwarunkowań innowacyjności w jednostkach samorządu terytorialnego. Empiryczną egzemplifikacją przedmiotowej problematyki innowacyjności administracji samorządowej są wyniki badań socjologicznych z terenu województwa podkarpackiego.

\section{Wprowadzenie}

Rezultatem procesu decentralizacji władzy jest zwiększenie zarówno zakresu samodzielności i kompetencji, jak i zadań oraz obowiązków struktur administracji samorządowej każdego szczebla. Ważna rola w realizacji polityki rozwoju społeczno-gospodarczego przypada samorządowi województwa. Do jego podstawowych zadań w tym zakresie należy tworzenie

\section{SŁOWA KLUCZOWE}

INNOWACYJNOŚĆ, POSTAWA, BIUROKRACJA, INSTYTUCJE ADMINISTRACJI SAMORZĄDOWEJ 
warunków rozwoju gospodarczego, pobudzanie aktywności gospodarczej, działanie na rzecz podnoszenia konkurencyjności i innowacyjności gospodarki województwa, a także wspieranie rozwoju nauki, współpracy sfery nauki i biznesu oraz popieranie postępu technologicznego i innowacji.

Z punktu widzenia zasadniczej roli administracji samorządowej w kreowaniu procesów rozwojowych na poziomie lokalnym i regionalnym szczególnego znaczenia nabiera kwestia innowacyjności jednostek organizacyjnych samorządu terytorialnego. Innowacyjność i otwartość na zmiany może być w tym przypadku ujmowana w aspekcie postaw indywidualnych oraz działań instytucjonalnych. Postawy i przekonania odnoszą się do sfery świadomości i wyrażają się w mniej lub bardziej skrystalizowanych nastawieniach personelu (urzędników) instytucji samorządowych wobec innowacji. Działania instytucjonalne to zróżnicowana co do zakresu i form aktywność innowacyjna jednostek administracji samorządu terytorialnego. Analizy i charakterystyki innowacyjności administracji samorządowej będące rezultatem empirycznego oglądu tego zjawiska (na podstawie badania jednostek samorządu terytorialnego wszystkich szczebli w województwie podkarpackim¹) należy poprzedzić naszkicowaniem kontekstu teoretycznego przedmiotowej problematyki.

\section{Innowacyjność a struktury administracyjne}

Problematyka innowacyjności administracji samorządowej to interesujące pole zarówno refleksji teoretycznej, jak i badań empirycznych. Instytucjonalne struktury administracji samorządowej należą do typu organizacji o atrybutach biurokracji. Według Maxa Webera (2002) w nowoczesnym społeczeństwie organizacja w najwyższym stopniu sprawna i racjonalna ma cechy biurokracji. Idealnotypowa biurokracja to określony typ organizacji. Jej jednostkami są organy o hierarchicznej strukturze, mające swoje zadania, funkcje, sformalizowany obieg pisanych dokumentów, odpowiednie środki przymusu (Ritzer, 2004, s. 163). Głównymi cechami biurokracji, będącej „najczystszym typem legalnego panowania” (Weber, 2002, s. 163-164), są:

- ciągłe zobowiązanie do respektowania pewnych reguł załatwianie spraw urzędowych;

- określenie zakresu kompetencji każdego organu oznaczające rzeczowo ograniczony zakres obowiązków wynikający z podziału zadań;

- przypisanie niezbędnych dla danego zakresu obowiązków uprawnień rozkazodawczych;

- określenie dopuszczalnych środków przymusu oraz przesłanek ich stosowania;

- zorganizowanie poszczególnych organów w sposób hierarchiczny;

- fachowe wyszkolenie (wykształcenie) osób zatrudnionych w strukturze biurokratycznej, umożliwiające stosowanie zarówno reguł technicznych, jak i norm rządzących postępowaniem organów;

- całkowite oddzielenie personelu urzędniczego organów od środków administrowania urzędnicy nie mogą mieć na własność żadnej części organizacji;

- wykluczenie możliwości jakiegokolwiek zawłaszczenia stanowiska urzędowego przez pia-

stującą je osobę;

- dokumentowanie w formie pisemnej wszelkich decyzji, zarządzeń, rozporządzeń.

1 Badanie zrealizowano w ramach projektu celowego Ministerstwa Nauki i Informatyzacji nr 6 RSI 2003/5997: „Regionalna Strategia Innowacji dla Województwa Podkarpackiego". Wyniki badań oraz oparte na nich analizy i charakterystyki innowacyjności administracji publicznej Podkarpacia zawarto w książce: Tuziak, Tuziak, Bobrecka-Jamro, Jastrzębska (2006). 
Praktyczne funkcjonowanie systemu biurokracji wiąże się z pewnymi ograniczeniami i może powodować zjawiska niepożądane. Struktury biurokratyczne niezdolne są do sprawnego działania w przypadku sytuacji nietypowych, tj. nieujętych w obowiązujących przepisach. Mają również poważne problemy z wdrażaniem innowacji, wymagających z reguły zmiany sposobu myślenia i działania, a także reorganizacji istniejącej struktury organizacyjnej. Ograniczenia biurokracji wiążą się również z konfliktami między ekspertami, dla których autorytetem jest wiedza, a urzędnikami bazującymi na hierarchii urzędniczej. W organizacjach biurokratycznych może pojawić się przenoszenie celów przejawiające się tym, że: przestrzeganie przepisów staje się ważniejsze od realizacji celów organizacji; organizacja skupia się na własnym funkcjonowaniu zamiast na świadczeniu usług; organizacja szuka nowych celów w sytuacji, gdy te, do których została powołana, zostały już zrealizowane. Wreszcie, w organizacji biurokratycznej mogą pojawić się grupy nieformalne wywierające duży wpływ na jej funkcjonowanie, głównie w odniesieniu do zdobywania władzy i realizacji partykularnych interesów (Szacka, 2003, s. 216-219).

Analizując mechanizmy i przejawy dysfunkcji biurokracji, Robert K. Merton (1982, s. 257260) zwrócił uwagę na kilka negatywnych zjawisk. Według autora Teorii socjologicznej i struktury społecznej do najczęściej występujących w organizacji biurokratycznej napięć i deformacji należą:

- wyuczona nieudolność - sytuacja, w której umiejętności i sprawdzone (efektywne) w przeszłości praktyki działań prowadzą w zmienionych warunkach do niewłaściwych reakcji; mała elastyczność stosowania zdobytych umiejętności powoduje problemy z przystosowaniem do nowych okoliczności;

- psychoza zawodowa - jednostki w wyniku rutyny rozwijają zespół negatywnych cech i nastawień przejawiających się w postaci różnych uprzedzeń i antypatii;

- dosłowne rozumienie i drobiazgowe przestrzeganie przepisów, będące rezultatem dyscy-

plinującej presji wywieranej na urzędników i prowadzące do przemieszczenia celów i zachowań o znamionach rytualizmu i formalizmu;

- nadmierny konformizm mający źródło w strukturalnych cechach organizacji biurokratycznej.

Należy zauważyć, że we współczesnej literaturze socjologicznej sam termin „biurokracja” bywa interpretowany na kilka sposobów. Według Stanisława Andreskiego (1992, s. 133) terminu „biurokracja” używa się w czterech różnych znaczeniach. Biurokracja to określony zbiór ludzi pełniących funkcje administracyjne w sposób opisany przez Webera; sieć relacji wiążących tych ludzi; obszar władzy, którą posiadają jako grupa; różne rodzaje i przejawy złego funkcjonowania machiny administracyjnej.

W kontekście zarysowanej powyżej specyfiki organizacji biurokratycznej (z natury rzeczy niesprzyjającej postawom innowacyjnym) trudno jednoznacznie określić zakres przedmiotowy innowacyjności w odniesieniu do jednostek administracji samorządowej, które funkcjonują według zasad i reguł zawartych w systemie uregulowań formalnoprawnych. Innowacyjność jest bowiem zjawiskiem wielopostaciowym, łączącym aspekty psychologiczne, socjologiczne, ekonomiczne, a także aksjologiczne i etyczne. Mimo znacznej różnorodności występujących w literaturze przedmiotu sposobów definiowania innowacji (zob. Tuziak, 2013, s. 46-56) nie ulega wątpliwości, że można ją traktować przede wszystkim jako szczególny rodzaj zmiany. Specyfika innowacji ujmowanej jako przejaw zmiany polega na tym, że jest ona ze swej natury twórcza i zarazem korzystna w różnych wymiarach - technologicznym, organizacyjnym, instytucjonalnym (Marciniak, 1998; Maillat, Kebir, 1999). Nieodłączną cechą innowacji jest również nowość. Według Wacława Makarczyka (1971, s. 9) 
innowacje to wszelkie wartości kulturowe, które w danych warunkach czasowo przestrzennych są traktowane przez ludzi jako nowe. Wyznaczając podstawowy zakres pojęcia innowacji w odniesieniu do administracji samorządowej (jako określonego typu organizacji), można przyjąć, że jest ona „procesem polegającym na przekształceniu istniejących możliwości w nowe idee i wprowadzeniu ich do praktycznego zastosowania" (Okoń-Horodyńska, 2003, s. 47).

Fakt, że instytucje administracji samorządowej mają cechy organizacji biurokratycznej, stanowi pewną trudność w empirycznym rozpoznaniu form i zakresu ich innowacyjności. Ujęcie zagadnienia innowacyjności administracji samorządowej w odniesieniu do sfery postaw i działań innowacyjnych to specyficzny i złożony obszar eksploracji badawczej. Trudności metodologiczne i realizacyjne wiążą się m.in. z faktem, że sfera postaw obejmuje zjawiska o złożonej strukturze, wielorako uwarunkowane i łączące się z procesami wartościująco-motywacyjnymi przebiegającymi w świadomości jednostkowej i zbiorowej (Tuziak, Tuziak, Bobrecka-Jamro, Jastrzębska, 2006, s. 16-19). Postawy z reguły nie są w pełni ukształtowane i uporządkowane. Wiedza na poziomie jednostkowym często cechuje się mniejszą lub większą niespójnością. Poza tym sprzeczności i ambiwalencja mogą pojawić się nie tylko na poziomie poznawczym, lecz także aksjologicznym i motywacyjnym. Złożoność i różnorodność obiektu postawy, czyli innowacji, znacząco wpływa na złożoność i stopień wewnętrznej spójności postaw wobec niego.

Postawa jest tworem o złożonej strukturze i licznych powiązaniach pomiędzy elementami tej struktury. Na strukturę postawy składają się trzy komponenty: emocjonalno-oceniający, poznawczy, behawioralny (Nowak, 1973, s. 23-31). Komponent emocjonalno-oceniający ma charakter mniej lub bardziej zintelektualizowanych ocen, wyraża się w postaci dodatnich lub ujemnych emocji związanych z przedmiotem postawy. Na komponent poznawczy składają się przekonania i wiedza o przedmiocie postawy. Komponent behawioralny to mniej lub bardziej jednorodny zespół dyspozycji do zachowania się w określony sposób wobec obiektu postawy. Komponenty konstytuujące postawę są wzajemnie powiązane, tworząc złożoną całość, w której poszczególne składniki są w różnym stopniu rozwinięte i wywierają na siebie wpływ. Bazując na podstawowej definicji postawy (Nowak, 1973, s. 23-31), można postawę innowacyjną podmiotu określić jako ogół względnie trwałych dyspozycji do oceniania innowacji i emocjonalnego na nią reagowania oraz towarzyszących tym emocjonalno-oceniającym dyspozycjom względnie trwałych przekonań o naturze i własnościach innowacji i względnie trwałych dyspozycji do określonego zachowania się wobec innowacji.

\section{Innowacyjność w wymiarze postaw i przekonań}

Zasadnicze badanie dotyczące zakresu, form, uwarunkowań i przejawów innowacyjności administracji publicznej województwa podkarpackiego przeprowadzono w 2004 roku (a kontynuowano w latach 2006-2007 jako monitoring społecznych efektów wdrażania RSI województwa podkarpackiego) w ramach projektu celowego Ministerstwa Nauki i Informatyzacji, którego rezultatem było opracowanie strategii innowacji dla województwa. Badaniem objęto wszystkie jednostki administracji - od szczebla gminnego przez powiatowy do wojewódzkiego. W badaniu zastosowano ankietę pocztową skierowaną do 159 urzędów gmin, 21 urzędów powiatowych oraz do Urzędu Marszałkowskiego i Podkarpackiego Urzędu Wojewódzkiego. Ponadto poddano analizie strategie rozwoju lokalnego opracowane na poziomie powiatów. 
Empiryczne rozpoznanie innowacyjności i stopnia otwartości na zmiany przedstawicieli personelu jednostek administracji samorządowej województwa podkarpackiego przeprowadzono głównie w toku analizy trzech komponentów postaw wobec innowacji: poznawczego, emocjonalno-oceniającego i behawioralnego (Tuziak i in., 2006, s. 83-97). W pierwszej kolejności starano się ustalić stan i poziom wiedzy respondentów na temat innowacji, a także samo rozumienie tego pojęcia. Badania wykazały, że rozumienie istoty innowacji przez badanych cechowało się znaczną różnorodnością. Dominujące jednak okazało się ujmowanie tego pojęcia w kategoriach bardzo ogólnych. Ponad jedna trzecia respondentów nie wskazała żadnych cech ani nie sformułowała pełniejszych charakterystyk innowacji, ograniczając się jedynie do stwierdzenia, że jest to „coś nowego”. Tę ogólnikowość rozumienia innowacji należy uznać za przejaw niedostatecznego rozwinięcia komponentu poznawczego postaw respondentów.

Badani, którzy z nieco większą precyzją określali innowację, mieli tendencję do wąskich ujęć tego terminu - głównie w kategoriach technicznych. Wielowymiarowe ujęcia akcentujące nowatorstwo w metodach organizacji i zarządzania pojawiały się stosunkowo rzadko. Ten aspekt innowacyjności - jak należy przypuszczać - ze względu na biurokratyczny charakter struktur administracyjnych, w których zawodowo funkcjonują respondenci, nie był przez nich uznawany za istotny. Elementy, które w wymiarze świadomościowym decydują o innowacyjności, czyli nieschematyczność myślenia, kreatywność i otwartość na zmiany, były dostrzegane przez badanych w najmniejszym stopniu.

Personel jednostek administracji samorządowej, które regularnie współpracują z zagranicą (tego rodzaju współpracę zadeklarowała niemal połowa przebadanych urzędów), częściej niż w pozostałych ujmował innowacje w szerszej perspektywie, wskazując, że polegają one głównie na usprawnieniach w organizacji pracy i zarządzaniu ludźmi, a także na wprowadzaniu nowych lub ulepszonych produktów i usług. Najpełniejsze rozumienie innowacji podkreślające jej procesowy, dynamiczny i twórczy charakter zidentyfikowano w urzędach, które zadeklarowały, że wdrożyły lub wdrażają systemy zarządzania jakością (stanowiły one zaledwie jedną ósmą wszystkich przebadanych jednostek).

Badanie miało także na celu identyfikację źródeł wiedzy respondentów na temat innowacji. Ustalono, że najczęściej występujące źródła uzyskiwania przez badanych informacji o innowacjach to (w kolejności wskazań): prasa, szkolenia, Internet, radio i telewizja oraz czasopisma fachowe. W dalszej kolejności jako istotne kanały i sposoby przekazu informacji na ten temat respondenci wskazali kontakty z innymi jednostkami administracji (urzędami), konferencje naukowe oraz targi i wystawy. Najrzadziej wskazywanymi źródłami wiedzy o innowacjach były szkoły wyższe oraz ośrodki badawczo-rozwojowe. Może to świadczyć o tym, że kontakty i rzeczywista współpraca w zakresie innowacji między jednostkami administracji samorządowej a instytucjami naukowymi są dalece niewystarczające. Przyczyny tego stanu rzeczy w pewnym stopniu tkwią w codziennej praktyce funkcjonowania jednostek samorządowych. Często nie dostrzegają one potrzeby kontaktów i współpracy z placówkami naukowymi i ośrodkami badawczo-rozwojowymi w rozwiązywaniu bieżących problemów. Raczej rzadko korzystają z pomocy kadry naukowej wyższych uczelni przy opracowywaniu lokalnych strategii rozwojowych. Ograniczenie kontaktów może też wynikać z nieznajomości oferty współpracy placówek naukowo-badawczych, a w wielu przypadkach także z fizycznego oddalenia jednostek administracji terenowej od centrów, w których zlokalizowane są wyższe uczelnie i ośrodki badawczo-rozwojowe. Nie sprzyja to nawiązywaniu współpracy i podnosi koszty wzajemnych kontaktów. 
Za jeden ze wskaźników komponentu poznawczego postaw innowacyjnych respondentów uznano wiedzę na temat instytucji i organizacji zajmujących się wprowadzaniem lub wspieraniem innowacji. Okazało się, że nieco ponad połowa badanych nie zna żadnych tego rodzaju instytucji. Spośród typów instytucji wprowadzających lub wspierających innowacje, wyszczególnionych ze względu na terytorialny zasięg działania respondenci wskazywali przede wszystkim na regionalne, ogólnopolskie i lokalne. Wśród instytucji regionalnych najczęściej wymieniano Rzeszowską Agencję Rozwoju Regionalnego. Najbardziej znaną przez respondentów instytucją ogólnopolską okazała się Polska Agencja Rozwoju Przedsiębiorczości. W kategorii instytucji lokalnych najczęściej wskazywano Fundację Rozwoju Powiatu Jasielskiego. Część badanych wskazywała nie tyle nazwy własne konkretnych instytucji, ile ogólne kategorie, m.in. uczelnie, instytuty naukowe, fundacje międzynarodowe, inkubatory przedsiębiorczości, ośrodki badawczo-rozwojowe, agencje rozwoju.

W celu ustalenia poziomu otwartości na zmiany i innowacje oraz gotowości ponoszenia ryzyka określonych działań (wymiar behawioralny postaw) poddano analizie stopnień akceptacji przez respondentów stwierdzeń dotyczących różnych sfer i aspektów życiowej aktywności. Ponad połowa respondentów zgodziła się ze stwierdzeniem, że eksperymentowanie, wprowadzanie zmian i nowych rozwiązań przynosi więcej korzyści niż strat. Ze stwierdzeniem, że ważne jest, aby w pracy realizować swoje pomysły, zgodziło się ponad trzy piąte badanych. Świadczy to o tym, że ogólne nastawienie respondentów wobec zmian oraz indywidualnej aktywności i pomysłowości było afirmatywne, mogące stanowić podstawę rozwijania postaw otwartości i akceptacji wobec innowacji.

Opinie na temat tego, czy należy trzymać się w postępowaniu sprawdzonych wzorów, były wśród badanych podzielone, a ponad jedna trzecia z nich nie potrafiła określić jednoznacznie swojego stanowiska w tej kwestii. Postawa wobec ryzyka (związanego m.in. ze skłonnością do odchodzenia od rutynowych działań) jest jednym z wyznaczników stosunku do zmian, w tym także do zmian innowacyjnych, które ze swej istoty obarczone są dużą dozą niepewności i ryzyka. Ponad jedna trzecia badanych nie potrafiła jednoznacznie ustosunkować się do stwierdzenia, że należy unikać ryzyka. Ponad jedna piąta wyraziła akceptację dla tego poglądu, a prawie jedna trzecia nie była skłonna zaakceptować wskazania zalecającego unikanie ryzyka. Niejednoznaczny stosunek do ryzyka ujawnia ambiwalencję i niespójność postaw badanych, zwłaszcza w zestawieniu z faktem, że większość z nich wyraziła przekonanie, że ważne jest, aby rozwijać własną fantazję i kreatywność oraz wprowadzać nowe wartości w sferze działań będących w zakresie własnych kompetencji i uprawnień.

Wśród badanych przedstawicieli jednostek administracji samorządowej stwierdzono wysokie deklarowane poparcie dla wprowadzania innowacji w sferze zarządzania i kierowania zespołami ludzkimi. Deklaracjom tego typu nie towarzyszyły jednak, na takim poziomie, jakiego należałoby oczekiwać, działania i rozwiązania innowacyjne. Podejmowano je bowiem w niespełna jednej trzeciej przebadanych urzędów, a dotyczyły one głównie zmian w strukturze organizacyjnej, wprowadzania zarządzania przez jakość i tworzenia zespołów zadaniowych. Generalnie komponent behawioralny postaw, czyli dyspozycje do podejmowania określonych działań, nie miał jednoznacznego charakteru i był stosunkowo słabo rozwinięty.

Na zakończenie tej części opisu rezultatów poznawczych przeprowadzonych badań należy jeszcze krótko scharakteryzować komponent emocjonalno-oceniający postaw wobec innowacji. Okazało się, że odczucia badanych w tym względzie nacechowane są znaczną ambiwalencją. Wyraziła się ona w akceptacji stwierdzenia, że innowacje wzbudzają 
zarówno obawy, jak i nadzieje. Owa ambiwalencja koresponduje z niejednoznacznością opinii na temat ryzyka i słuszności respektowania sprawdzonych wzorów postępowania. Warto jednak podkreślić, że u blisko jednej trzeciej badanych innowacje wzbudziły wyłącznie nadzieje. Należy to uznać za przejaw sprzyjającego klimatu emocjonalnego dla zmian innowacyjnych, który może się ugruntowywać, zwłaszcza gdy rozwiązania innowacyjne będą przynosić wymierne korzyści.

\section{Innowacyjność w wymiarze instytucjonalnym}

Aktywność innowacyjna przebadanych jednostek administracji samorządowej cechowała się znacznym zróżnicowaniem co do form i zakresu (Tuziak i in., 2006, s. 127). Jej organizacyjny, „wewnętrzny” wymiar związany był głównie z funkcjonowaniem urzędów, a w szczególności z metodami zarządzania ludźmi. Zmiany i rozwiązania organizacyjne dotyczyły przede wszystkim organizacji (usprawnienia) pracy urzędów. Konkretyzowały się m.in. przez usamodzielnienie (decyzyjne) stanowisk pracy, zgrupowanie zadań i zagadnień według spraw pokrewnych oraz wielofunkcyjność stanowisk. Badania wykazały, że urzędy podejmowały również starania o lepsze dostosowanie swojego funkcjonowania do potrzeb mieszkańców m.in. przez analizę pracochłonności czynności administracyjnych na poszczególnych stanowiskach, unowocześnienie i usprawnienie sposobu obsługi interesantów oraz dążenie do zatrudniania osób o wysokich, potwierdzonych dyplomem wyższych uczelni, kwalifikacjach. Ponadto w niektórych urzędach opracowano nowe regulaminy organizacyjne, których celem było głównie podnoszenie poziomu jakości pracy, wprowadzono kodeksy etyki pracownika samorządowego, wdrożono programy szkoleń z różnych dziedzin, m.in. promocji gminy i obsługi interesantów. Te różnorodne zmiany, usprawnienia i innowacje zrealizowano w niespełna jednej trzeciej przebadanych urzędów.

Współpracę w zakresie innowacji z instytucjami zewnętrznymi zadeklarowało ponad trzy piąte jednostek administracji samorządowej. Urzędy najczęściej współpracowały z agencjami rozwoju regionalnego i inkubatorami przedsiębiorczości, a w dalszej kolejności ze szkołami wyższymi oraz małymi i średnimi przedsiębiorstwami (MŚP). Uszczegółowiając rozpoznanie charakteru współpracy z instytucjami zewnętrznymi w zakresie innowacji, ustalono, czego konkretnie ta współpraca dotyczyła. W większości przebadanych jednostek samorządowych wskazano, że współpraca dotyczyła szkoleń i kursów. Ponadto obejmowała także przygotowanie wniosków o środki z funduszy unijnych. Należy zaznaczyć, że deklaracji badanych urzędów nie poddano weryfikacji z powodu braku możliwości czasowych i technicznych takich działań. Nie można zatem wykluczyć, że rzeczywisty stan i zakres współpracy kształtował się na niższym poziomie, niż deklarowano.

Badania wykazały, że ponad trzy piąte jednostek samorządu terytorialnego nie podejmowało działań mających na celu promowanie innowacji. Wśród pozostałych urzędów, które takie działania podejmowały, przedmiotem promocji były przede wszystkim nowe (ulepszone) usługi oraz nowe (ulepszone) metody organizacji i zarządzania. W mniejszym stopniu promocyjne przedsięwzięcia dotyczyły nowych produktów i technologii. W zakresie szeroko rozumianego promowania innowacji mieści się również wspieranie innowacyjnych MŚP. W ponad jednej trzeciej urzędów zadeklarowano wsparcie tego typu przedsiębiorstw. Dominujące metody (formy) wparcia to: przekazywanie informacji o funduszach pomocowych krajowych i unijnych skierowanych do MŚP, udostępnianie Internetu (stron www urzędów), udostępnianie terenów inwestycyjnych i nieruchomości oraz stosowanie zwolnień i ulg podatkowych. Wsparcie innowacyjnych MŚP przez urzędy przybierało też 
postać pośrednictwa w nawiązywaniu kontaktów i współpracy MŚP z innymi przedsiębiorstwami, instytucjami i organizacjami. Inną formą pomocy oferowanej przez urzędy administracji samorządowej małym i średnim firmom były usługi w zakresie doradztwa i szkoleń pracowników.

W administracyjnym wspieraniu innowacyjności na poziomie lokalnym i regionalnym podstawową rolę odgrywają instrumenty instytucjonalne i finansowe (Tuziak, 2006, s. 43-44). Z badań wynika, że instrumenty instytucjonalne rozwijane w gminach i powiatach województwa podkarpackiego to przede wszystkim ośrodki szkoleniowo-doradcze i inkubatory przedsiębiorczości, a w dalszej kolejności parki przemysłowe, centra transferu technologii i parki technologiczne. Najmniej instrumentów instytucjonalnych każdego typu rozwijano na poziomie gmin, a najwięcej na poziomie powiatów i w stolicy województwa. W kategorii instrumentów o charakterze finansowym, które wskazywano w urzędach, najczęściej występowały ulgi inwestycyjne. Inne instrumenty, w postaci funduszy pożyczkowych, funduszy poręczeniowych, funduszy dotacji inwestycyjnych oraz grantów badawczych, wskazywano znacznie rzadziej.

Badania wykazały, że wśród stymulatorów przedsiębiorczości (zarówno innowacyjnej, jak i tradycyjnej) stosowanych przez jednostki administracji najwyższą rangę przypisywano poprawie infrastruktury technicznej. Niemal równie ważna okazała się promocja walorów danego obszaru (gminy, powiatu, województwa). Na trzecim miejscu znalazło się usprawnienie funkcjonowania administracji samorządowej (Tuziak, 2006, s. 43-44). Wynika z tego, że przedstawiciele instytucji samorządu terytorialnego są świadomi faktu, że od jakości i sprawności ich pracy, zwłaszcza w zakresie obsługi administracyjnej inwestorów, zależy kształtowanie sprzyjającego klimatu dla przedsiębiorczości i innowacyjności w ramach danego układu lokalnego.

\section{Podsumowanie}

W odniesieniu do sfery szeroko rozumianej innowacyjności istotna jest identyfikacja i propagowanie dobrych praktyk w zakresie kreatywnej adaptacji do zmian i wyzwań rozwojowych. Zidentyfikowane dzięki badaniu i wyspecyfikowane według częstości występowania dobre praktyki w zakresie przedsięwzięć innowacyjnych jednostek samorządu terytorialnego województwa podkarpackiego można podzielić na dwie kategorie: dobre praktyki w wymiarze „wewnętrznym” dotyczące funkcjonowania i zarządzania urzędem oraz dobre praktyki „zewnętrzne” - dotyczące inicjatyw i działań innowacyjnych w zakresie rozwoju lokalnego i regionalnego (Tuziak i in., 2006, s. 185-187).

Dobre praktyki w zakresie zarządzania strukturami administracyjnymi polegały głównie na:

- przedsięwzięciach reorganizacyjnych podnoszących poziom efektywności działania urzędu oraz jakość świadczonych usług;

- działaniach na rzecz tworzenia systemu przepływu informacji między jednostkami admini-

stracji terenowej w celu koordynacji wspólnych działań;

- przeprowadzeniu komputeryzacji urzędu;

- tworzeniu zespołów zadaniowych;

- wprowadzaniu zarządzania przez jakość;

- uzyskaniu certyfikatów ISO;

- dbałości o rozwój kapitału ludzkiego organizacji;

- promocji nowych rozwiązań i własnych inicjatyw; 
- otwartości na współpracę z otoczeniem zewnętrznym;

- współpracy i wymianie personalnej z zagranicą;

- opanowaniu procedur pozyskiwania środków z funduszy pomocowych.

Dobre praktyki i innowacyjne przedsięwzięcia zidentyfikowane w zakresie zarządzania rozwojem lokalnym i regionalnym to:

- działania na rzecz rozwoju infrastruktury technicznej będącej podstawą rozwoju gospodarczego i warunkiem nadrabiania zapóźnieni cywilizacyjnych;

- koordynacja procesów dostosowywania podmiotów gospodarczych do standardów unijnych;

- tworzenie stref ekonomicznych;

- tworzenie inkubatorów przedsiębiorczości;

- tworzenie parków przemysłowo-technologicznych;

- działania stymulujące rozwój sektora MŚP;

- utworzenie funduszu poręczeń kredytowych;

- działania na rzecz budowania infrastruktury rynku;

- tworzenie ośrodków informacji i wspierania biznesu;

- tworzenie centrów informacji dla bezrobotnych;

- rozwijanie innowacyjnych metod promocji lokalnych walorów, produktów i usług;

- stosowanie systemu ulg podatkowych w celu zwiększenia atrakcyjności inwestycyjnej oraz pobudzenia rozwoju lokalnego;

- tworzenie systemu powiązań w postaci związków i porozumień gmin, powiatów w celu zwiększenia efektywności działań prorozwojowych;

- deklarowanie gotowości włączenia się w realizację regionalnej strategii innowacji.

Dzięki badaniom zidentyfikowano także bariery występujące w sferze innowacyjnych przedsięwzięć realizowanych przez jednostki administracji samorządowej. Główne ograniczenia i utrudnienia w podejmowaniu działań innowacyjnych, postrzegane z perspektywy samorząów to:

- brak możliwości finansowych wprowadzania rozwiązań innowacyjnych;

- obawa przed ryzykiem;

- niedostateczna współpraca między samorządem, biznesem a nauką;

- niewielki potencjał naukowo-badawczy regionu;

- słabo rozwinięta infrastruktura transportowa;

- brak sprzyjających regulacji prawnych, zmienność przepisów;

- brak odpowiednich lokali i powierzchni produkcyjnych;

- brak uzbrojonych terenów;

- brak wiedzy o instrumentach i instytucjach wparcia firm;

- niskie lub nieodpowiednie kwalifikacje siły roboczej.

Wyniki badań upoważniają do ogólnego wniosku, że konsekwentne tworzenie otoczenia sprzyjającego działalności gospodarczej, przedsiębiorczości i innowacyjności jest jedną z najważniejszych sfer działań samorządów terytorialnych ukierunkowanych na podnoszenie tempa i efektywności lokalnego rozwoju społeczno-gospodarczego. Potwierdziły one także hipotezę o dwojakim uwarunkowaniu poziomu innowacyjności administracji samorządowej. Zidentyfikowano zarówno zewnętrzne, jak i wewnętrzne determinanty postaw i działań innowacyjnych. Pierwsze tkwią w obiektywnych uwarunkowaniach systemowych wyrażających się m.in. w postaci uregulowań formalnoprawnych, możliwościach lokalnych budżetów, strukturze własnych i zleconych zadań samorządów. Drugie zlokalizowane są 
w sferze świadomości indywidualnej i grupowej i objawiają się w wyraźnie artykułowanej obawie przed ryzykiem i zmianami, a także w tendencji do swego rodzaju bierności i zachowawczości, po części zapewne wynikającej z biurokratycznej natury instytucji władzy samorządowej. W wymiarze praktycznym badania pozwoliły na sformułowanie szczegółowych wniosków diagnostyczno-projekcyjnych, a także zaleceń i wskazań realizacyjnych wykorzystanych przy tworzeniu Regionalnej Strategii Innowacji dla Województwa Podkarpackiego na lata 2005-2013, stanowiącej (w zaktualizowanej postaci) jeden z podstawowych instrumentów realizacji regionalnej polityki innowacyjnej przez wojewódzkie władze samorządowe.

Należy dodać, że badania, których główne wyniki przedstawiono skrótowo w artykule, stały się jedną z istotnych motywacji do podjęcia empirycznego rozpoznania roli innowacyjności w rozwoju regionu peryferyjnego (zob. Tuziak, 2013), stanowiąc zarazem ich znacznie rozszerzoną i odpowiednio ukierunkowaną kontynuację. Badania wykazały m.in., że czynnikiem w znacznym stopniu wpływającym na innowacyjność i konkurencyjność regionu są działania projektowe (których przykładem jest Regionalna Strategia Innowacji dla Województwa Podkarpackiego) podejmowane w określonym środowisku społeczno-kulturowym przez regionalne podmioty, wśród których proinnowacyjnie zorientowane władze samorządowe (zwłaszcza szczebla wojewódzkiego) odgrywają zasadniczą rolę.

\section{LITERATURA}

Andreski, S. (1992). Maxa Webera olśnienia i pomyłki. Warszawa: Wydawnictwo Naukowe PWN.

Maillat, D., Kebir, L. (1999). „Learning region” et systemes territoriaux de production. Revue d' Economie Regionale et Urbaine, 3, 429-448.

Makarczyk, W. (1971). Przyswajanie innowacji. Wrocław-Warszawa-Kraków-Gdańsk: Ossolineum, PAN.

Marciniak, S. (1998). Innowacje i rozwój gospodarczy. Warszawa: Wydawnictwo Politechniki Warszawskiej.

Merton, R.K. (1982). Teoria socjologiczna i struktura społeczna. Warszawa: PWN.

Nowak S. (1973). Pojęcie postawy w teoriach i stosowanych badaniach społecznych, W: S. Nowak (red.), Teorie postaw (s. 17-88). Warszawa: PWN.

Okoń-Horodyńska, E. (2003). Instytucjonalne struktury na rzecz innowacyjności w Polsce, Studia Ekonomiczne, 28, Innowacyjność a rozwój gospodarczy Polski: sity motoryczne i bariery, 45-65.

Ritzer, G. (2004). Klasyczna teoria socjologiczna. Poznań: Zysk i S-ka Wydawnictwo.

Szacka, B. (2008). Wprowadzenie do socjologii. Warszawa: Oficyna Naukowa.

Tuziak, A. (2006). Administracja publiczna w tworzeniu środowiska proinnowacyjnego. Ekonomika i Organizacja Przedsiębiorstwa, 3 (674), 42-49.

Tuziak, A., Tuziak B., Bobrecka-Jamro, D., Jastrzębska, W. (2006). Innowacyjność i rozwój. Zakres i formy aktywności innowacyjnej administracji publicznej Podkarpacia w procesie trwałego rozwoju regionu. Rzeszów: Wydawnictwo Uniwersytetu Rzeszowskiego. 
Tuziak, A. (2013). Innowacyjność w endogenicznym rozwoju regionu peryferyjnego. Studium socjologiczne. Warszawa: Wydawnictwo Naukowe Scholar.

Weber, M. (2002). Gospodarka i społeczeństwo. Zarys socjologii rozumiejącej. Warszawa: Wydawnictwo Naukowe PWN.

\section{INNOVATION IN THE INSTITUTIONS OF THE SECTOR OF LOCAL GOVERNMENTS}

SUMMARY The article presents the question of inventiveness in the institutions of the sector of local governments. At the beginning some general social regularities concerning inventiveness in organisations have been characterised, with a special attention paid to bureaucratic institutions. In the main part of the article the author concentrates on individual and institutional conditions of inventiveness in the bodies of local governments. The empirical exemplification of the problems of inventiveness in the local administration are the results of sociological research conducted in the Podkarpackie Voivodeship.

\section{KEYWORDS}

INVENTIVENESS,

ATTITUDE, BUREAUCRACY, INSTITUTIONS OF LOCAL GOVERNMENTS 
